(C) 1980. The Genetical Society of Great Britain

\title{
REITERATION FREQUENCY OF GENES CODING FOR ABUNDANT AND RARE MESSENGER RNA IN GREENED BARLEY SEEDLINGS
}

\author{
MANUEL KIPER, MARGRET BOLTE and FRANK HERZFELD \\ Institut für Botanik Universität Hannover Herrenhäuserstr. 23000 Hannover 21 GFR \\ Received 7.iii.80
}

\section{SUMMARY}

\begin{abstract}
Polysomal poly(A)mRNA was prepared from etiolated barley seedlings $8 \mathrm{~h}$ after light induced greening. The abundant class of mRNA containing about 15 different species was purified. Total and abundant class poly(A)mRNA was examined by hybridization to genomic DNA present in great excess. Total poly(A)mRNA representing 20,000 to 30,000 different species hybridizes exclusively with single-copy DNA. The abundant class mRNA hybridizes with barley DNA with kinetics corresponding to fewer than 5 gene copies per haploid genome.
\end{abstract}

\section{INTRODUCTION}

HigheR plants are characterized by the presence of a large fraction of repetitive sequences often exceeding more than 70 per cent of the whole genome (Flavell et al., 1974). The genome size varies from about 0.1 to $100 \mathrm{pg}$ (Rees and Jones, 1972), while the relative amount of repetitive DNA progressively increases with genome size (Thompson, 1978). The function of this repetitive DNA is unknown. Although reiterated structural genes are known (Weinberg et al., 1972) many proteins characteristic of animal specialized tissue, for example globin (Harrison et al., 1972) or ovalbumin (Harris et al., 1973) are coded for by single- or few-copy DNAs.

Plant leaves contain much ribulose-1,5-bisphosphate $\left(\mathrm{Ru}-\mathrm{P}_{2}\right)$ carboxylase, the light-harvesting chlorophyll $a / b$ protein and other proteins (Cashmore, 1976). These structural proteins of plant leaf chloroplasts are not all encoded by the nuclear genome; some are coded by the chloroplast genome, for example the large subunit of the $\mathrm{Ru}-\mathrm{P}_{2}$ carboxylase (Coen et al., 1977). As the chloroplast DNA is reiterated several thousandfold in cells of green leaves (Lamppa and Bendich, 1979) we wished to establish whether genes for abundant leaf proteins encoded by the nuclear genome are reiterated accordingly.

Barley possesses a large haploid genome size of $6.7 \mathrm{pg}$ and only a small proportion of single-copy DNA (Flavell et al., 1974; Kiper et al., 1979b). We have demonstrated that after light induced greening of etiolated barley leaves a substantial fraction of functional mRNA consists of a few abundant species freshly synthesized (Heinze et al., in preparation). One of these major species produced after light induction is the messenger for the light harvesting protein (Apel and Kloppstech, 1978). We report here studies on the degree of reiteration in the nuclear genome of genes coding for rare and abundant leaf poly $(\mathrm{A})^{+}-\mathrm{mRNAs}$ after light induction of greening. 


\section{MATERIALS AND METHODS}

(i) Growth of plants

Wild-type barley (Hordeum vulgare) was grown in the dark on moist vermiculite at $25^{\circ} \mathrm{C}$ for 5 days. Plants were illuminated for $8 \mathrm{~h}$ with incandescent light. Leaves and roots were harvested and immediately frozen in liquid nitrogen and stored at $-80^{\circ} \mathrm{C}$.

\section{(ii) Preparation of DNA}

Nuclear DNA was extracted from barley roots. Tissue was broken and DNA extracted as described by Graham (1978). DNA was further purified according to the UP procedure described by Britten et al. (1974). Finally the DNA was incubated for $20 \mathrm{~h}$ at $37^{\circ} \mathrm{C}$ in $0.4 \mathrm{M} \mathrm{NaOH}$. DNA was neutralized with acetic acid. $15 \mathrm{ml}$ of the DNA solution were sonicated in a MSE ultrasonic Desintegrator for $1 \mathrm{~min}$ at an output of $1.4 \mathrm{~A}$. The DNA was spun down after addition of two volumes of ethanol. Chain length determination of DNA fragments was carried out by alkaline agarose gel electrophoresis and calibration with SV 40-Hae III digests and $\lambda$-Hind III digests as described previously (Kiper et al., 1979b). Single-copy DNA was isolated by two cycles of renaturation of $300 \mathrm{~N}$ long DNA to a $C_{0} t$ of 3000 and isolation of the single-stranded fraction by HAP chromatography. The single-copy DNA was incubated to a $C_{0} t$ of $10^{5}$ and labeled with ${ }^{3} \mathrm{H}$-dTTP in vitro using E.coli DNA polymerase I as described by Galau et al. (1976). The single-copy DNA prepared in this manner had a mean length of $250 \mathrm{~N}$.

\section{(iii) Isolation of poly $(A) m R N A$}

Polysomal RNA was prepared as described by Pfisterer and Kloppstech (1977). A modification was that the ground material was dissolved in a buffer of $p H 9$ and 0.01 EDTA, as described by Apel and Kloppstech (1978). Poly(A)mRNA was isolated by two rounds of oligo-dT-cellulose chromatography as described by Kloppstech and Schweiger (1976).

\section{(iv) Preparation of ${ }^{3} \mathrm{H}$ - and ${ }^{32} \mathrm{P}-\mathrm{cDNA}$}

cDNAs were synthesized from polysomal poly(A)mRNA according to the procedure of Friedman and Rosbash (1977) and essentially as described previously (Bartels and Kiper, 1979).

\section{(v) Isolation of cDNA complementary to prevalent poly $(A) m R N A$}

Total ${ }^{32} \mathrm{P}$-cDNA of polysomal poly(A)mRNA of greened barley leaves was hybridized with a more than 1000 fold excess of poly(A)mRNA to $C_{0} t$ 0.3 in $2 \times$ SSC-buffer. After dilution into S1 nuclease buffer (Davidson and Britten, 1973) $10 \mu \mathrm{g}$ each of single- and double-stranded calf thymus DNA were added and 100 fold over-digested with S1 nuclease. After phenolchloroform extraction the RNA was hydrolyzed by alkali treatment and the sample loaded on a sephadex G50 gel. The excluded fraction representing 8 per cent of the initial cDNA was pooled and ethanol precipitated. 


\section{(vi) Assay of hybridization and reassociation}

Annealing of DNA was performed as described previously (Kiper and Herzfeld, 1978). DNA/RNA hybridization reactions were carried out in $0.12 \mathrm{M}$ Phosphate buffer/0.5 per cent SDS at $60^{\circ} \mathrm{C}$ or in $0.4 \mathrm{M}$ phosphate buffer $/ 0.5$ per cent SDS at $64^{\circ} \mathrm{C}$ in sealed capillaries. The resulting $C_{0} t$ or $R_{0} t$ values were corrected to $0.18 \mathrm{M} \mathrm{Na}^{+}$as suggested by Britten et al. (1974). RNA and DNA concentrations were measured spectrophotometrically assuming $1 \mathrm{OD}=40 \mu \mathrm{g} / \mathrm{ml}$ RNA and $50 \mu \mathrm{g} / \mathrm{ml}$ DNA. Maximum DNA and RNA concentrations used were $8 \mathrm{mg} / \mathrm{ml}$. Tracer reactions were driven by an at least 1000 fold excess of the other component. DNA reassociation and single-copy DNA/nuclear DNA excess hybridization reactions were analyzed by HAP chromatography as described previously (Kiper, 1978) with the modification that the phosphate buffer was made 0.5 per cent in SDS. cDNA/RNA excess hybridization reactions were analyzed by $\mathrm{S} 1$ nuclease assay. Buffer conditions were those of Davidson and Britten (1973). $25 \mu \mathrm{g} / \mathrm{ml}$ native and $25 \mu \mathrm{g} / \mathrm{ml}$ denatured calf thymus DNA were added, the sample divided into two equal aliquots to one of which was added sufficient S1 nuclease to digest a 20 fold excess of DNA to acid solubility. Both aliquots were incubated for $45 \mathrm{~min}$ at $37^{\circ} \mathrm{C}$. The reactions were terminated by chilling on ice; both samples were then analysed for cold TCA precipitable radioactivity. Per cent duplex was calculated as cpm (sample with S1) to the cpm (sample without S1). Tracer zero time values ( $2-8$ per cent) were subtracted from the data. Reactions were analysed by a least square computer program.

\section{Results}

In principle, a small amount of radioactive nucleic acid added to a vast excess of nonradioactive genomic DNA can be used as a tracer in order to follow the reassociation of the genome complementary to the radioactive sequences. The kinetics of this reassociation can be used to estimate the reiteration frequency of this subset of the genome (Bishop, 1972).

\section{(i) Characterization of total and prevalent poly $(A)^{+} m R N A$}

Total polysomal poly $(\mathrm{A})^{+} \mathrm{mRNA}$ was isolated from etiolated barley seedlings $8 \mathrm{~h}$ after illumination. Sucrose gradient centrifugation proved the physical integrity of the polysomes. The extracted poly(A)mRNA was active in a cell-free translation system of wheat germ extract which suggests its biological function as mRNA. ${ }^{3} \mathrm{H}$-cDNA was prepared using avian reverse transcriptase (a gift of Dr Beard, St. Petersburg, Florida). The size of the cDNA was determined by agarose gel electrophoresis taking denatured SV $40 \mathrm{Hae}$-III digests as standards. The mean size turned out to be about 500 nucleotides. As can be seen in fig. 1 this radioactive probe reacted with a large excess of poly $(\mathrm{A}) \mathrm{mRNA}$ with kinetics extending over a wide range of $\log R_{0} t s$. Apparently the poly $(\mathrm{A})$ mRNA population comprises classes of different abundancy (Bishop et al., 1974). Computer analysis of the data revealed three abundance classes making up $26 \cdot 1,38 \cdot 3$ and $35 \cdot 6$ per cent of all mRNAs. Using as kinetic standard the hybridization reaction of rabbit globin mRNA with its complementary DNA $\left(k=260 \mathrm{M}^{-1} \mathrm{sec}^{-1}\right.$; 


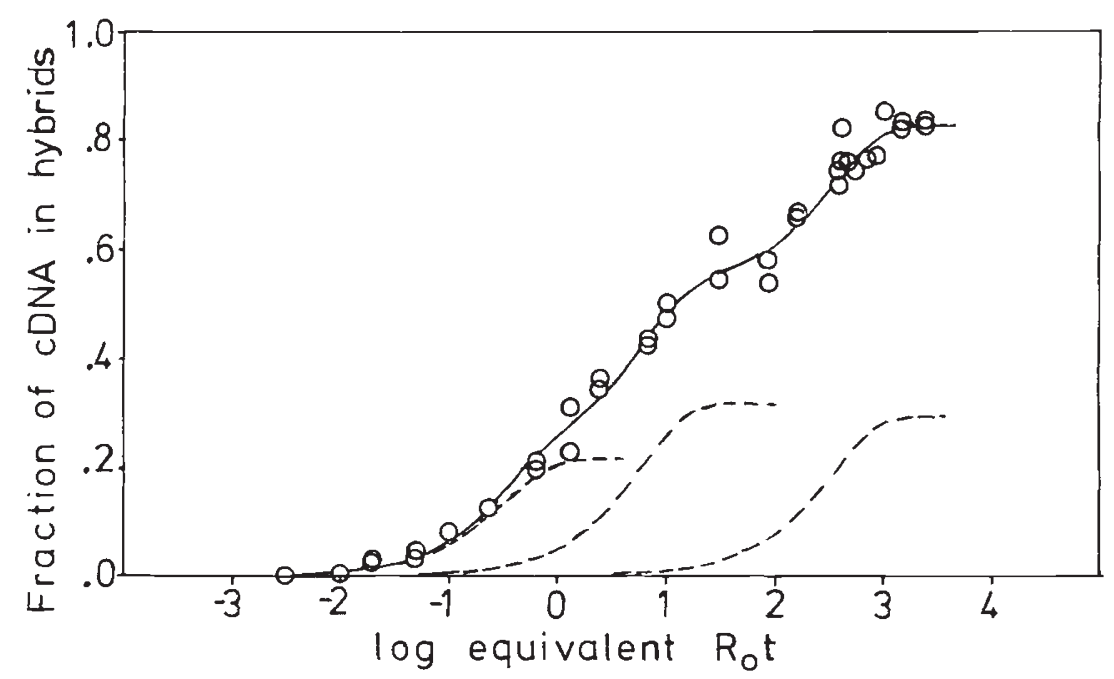

FIG. 1.-Hybridization between cDNA and its mRNA template of total polysomal poly(A)mRNA.

Total poly $(\mathrm{A}) \mathrm{mRNA}$ of greened barley leaves was transcribed into cDNA using ${ }^{3} \mathrm{H}-\mathrm{dCTP}$ for labeling. Specific activity of the cDNA was $2 \times 10^{6} \mathrm{cpm}$. For each point $5-10,000 \mathrm{cpm}$ were employed. Computer analysis of the data revealed three transitions with rate constants $k_{\text {pur }}$ of $13.92 ; 0.526 ; 0.00989 \mathrm{M}^{-1} \mathrm{sec}^{-1}$ making up $26 \cdot 1,38 \cdot 3,35.6$ per cent of the whole population. Comparing with the rate constant of $260 \mathrm{M}^{-1} \mathrm{sec}^{-1}$ for rabbit globin mRNA with its cDNA (Kiper et al., 1979b) this amounts to 15,395, and 21,030 different mRNAs of mean length $1500 \mathrm{~N}$.

Kiper et al., 1979 $b$ ) it can be calculated that the most abundant fraction has a complexity of $18.7 \times 1200$ nucleotide pairs. Taking $1500 \mathrm{~N}$ the mean molecular weight of the barley messengers this makes 15 out of about 22,000 different species. These mRNAs are about 3000 times as abundant as the slowest class of mRNAs making up the bulk of the complexity.

In order to isolate the reverse transcripts of the prevalent poly $(A) m R N A$ class, whole ${ }^{32} \mathrm{P}$-cDNA was prepared from poly(A)mRNA of greened leaves. Hybridization of this probe was driven to $R_{0} t 0 \cdot 3$. At this $R_{0} t$ value about half of the prevalent class of mRNA should have hybridized while more rare sequences should have had only a minimal chance to hybridize. Samples were overdigested 100fold with S1 nuclease in order to destroy all single stranded sequences. RNA was destroyed by alkaline hydrolysis. Nondigested ${ }^{32} \mathrm{P}$-cDNA which had been in hybrids was recovered by gel filtration. The exclusion peak represented about 8 per cent of the input radioactivity. Length determinations at half time of the following hybridizations displayed a mean length of 100-200 nucleotides.

Fig. 2 shows the hybridization of this radioactive probe with a vast excess of total poly(A)mRNA of greened barley leaves. Apparently the $R_{0} t_{1 / 2}$ of the reaction is similar to that for the prevalent class of messenger in fig. 1 . The retardation observed can be attributed to the reduced tracer length compared to the initial hybridization. A plateau of hybridization was reached at about $R_{0} t \quad 10$. This clearly demonstrates that the isolated prevalent cDNA essentially is free of the complex class sequences. The reduced reactability of the probe probably depends on the small size of the 


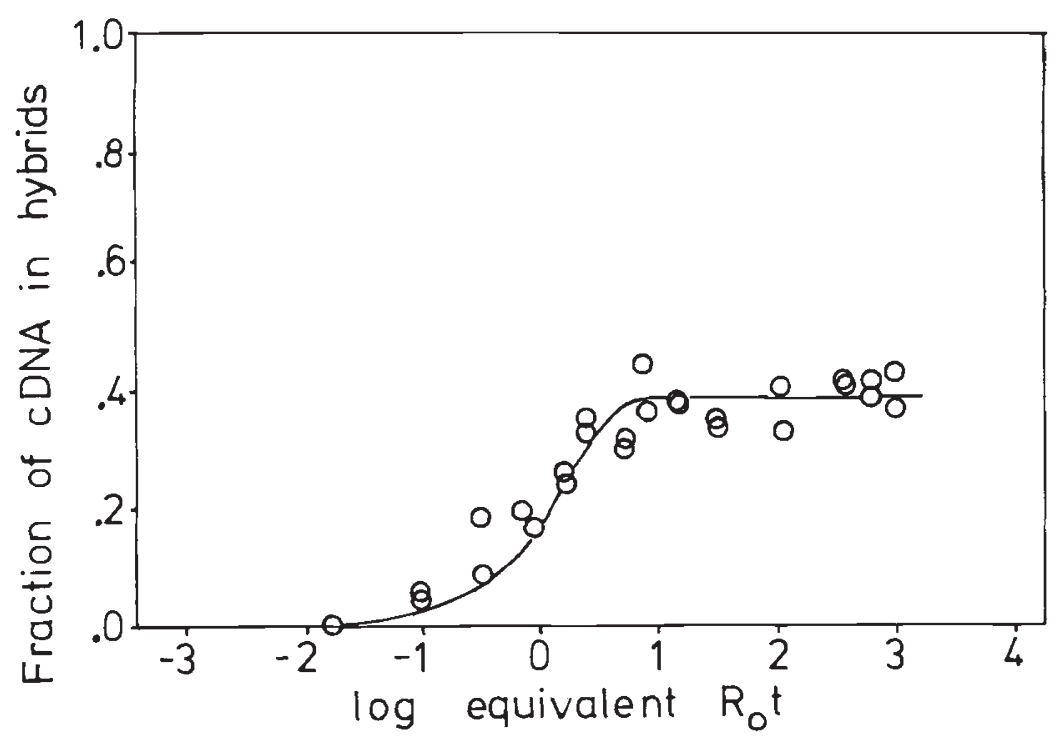

FIG. 2.-Hybridization between ${ }^{32} \mathrm{P}$-labeled prevalent cDNA and total poly(A)mRNA.

Poly(A)mRNA of greened leaves was hybridized with its complementary ${ }^{32} \mathrm{P}$-cDNA to $C_{0} t 0 \cdot 3$. Hybrids were collected ( 8 per cent of the total) and these prevalent cDNAs challenged with excess total poly(A)mRNA. The rate constant was $0.99 \mathrm{M}^{-1} \mathrm{sec}^{-1}$. Tracer length of the prevalent cDNA was $100-200 \mathrm{~N}$

tracers. Reaction of the probe with total poly(A)mRNA of etiolated barley leaves not shown here demonstrates that half of its mass consists of sequences appearing only during greening of leaves (Heinze et al., in prep.). Hence it is clear that the purified probe is a representative probe of prevalent sequences expressed during greening of barley leaves.

\section{(ii) Hybridization studies to DNA}

The nuclear DNA of barley as most other eukaryotic genomes comprises sequences of different reiteration. The dashed curve in fig. 3 represents the renaturation kinetics of $300 \mathrm{~N}$ nuclear DNA (Kiper et al., 1979a). Apparently most of the genome consists of sequences renaturing at $C_{0} t s$ characteristic of repetitive DNA. Only a relatively small amount renatures between $\log C_{0} t s 2 \cdot 5-5 \cdot 0$ supposed to be single-copy DNA according to the haploid genome size of barley. The kinetics of a purified single-copy DNA tracer about 250-300 N long with a large excess of $700 \mathrm{~N}$ long whole nuclear DNA is seen in fig. 4 as the ideal curve (Kiper et al., 1979a). This isolated single-copy DNA reassociated with a rate constant of $0.3 \times 10^{-3} \mathrm{M}^{-1} \mathrm{sec}^{-1}$.

Fig. 3 represents the hybridization kinetics of whole poly $(\mathrm{A})^{+} \mathrm{mRNA}$ of greened barley leaves with total nuclear DNA of barley roots. Though in higher plants it is uncertain whether poly $(\mathrm{A})^{+} \mathrm{mRNAs}$ are coded for by the chloroplast genome, root nuclear DNA displays minimal contamination by chloroplast DNA (Pascoe and Ingle, 1978; Lamppa and Bendich, 1979) and thus is best adapted for these hybridization studies. Apparently the kinetics display only one major component reacting between $\log R_{0} t 2 \cdot 5-4 \cdot 5$. The 


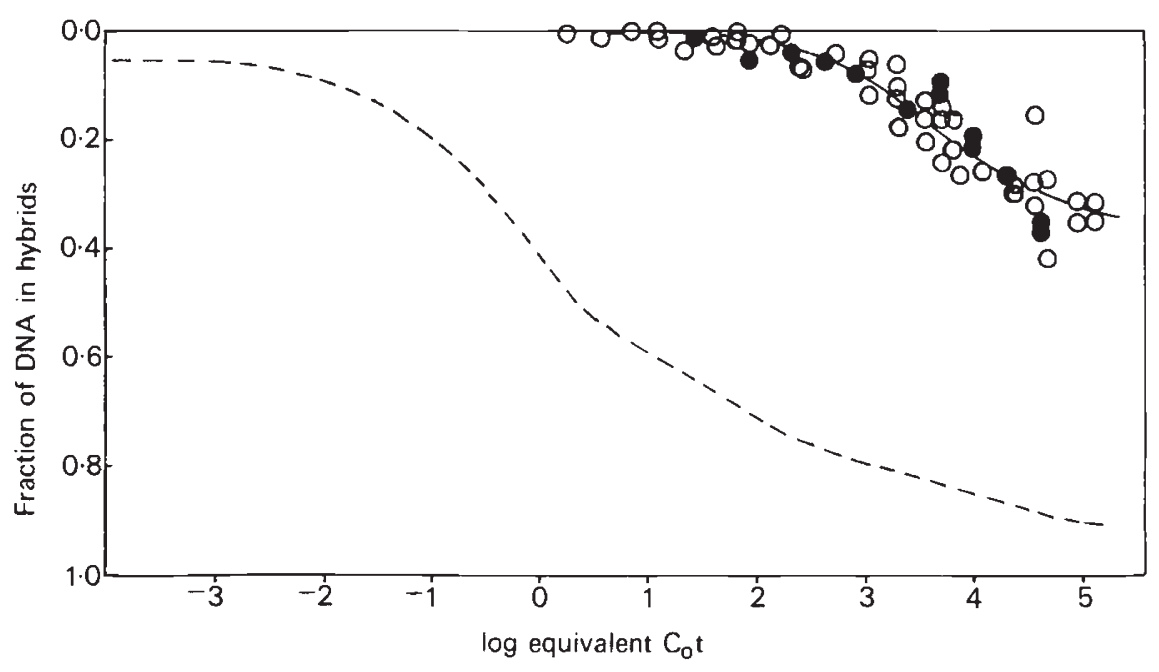

FIG. 3.- Hybridization of total ${ }^{3} \mathrm{H}$-cDNA with total nuclear DNA.

Total ${ }^{3} \mathrm{H}$-cDNA complementary to poly $(\mathrm{A})$ mRNA of greened leaves was hybridized with a 100,000 fold excess of total root nuclear DNA. Samples were analysed by S1 nuclease digestion $(O)$ or by HAP-chromatography $(O)$. The dashed curve represents the reassociation of total nuclear DNA as described by Kiper et al. (1979a). The rate constant was $0.6 \times$ $10^{-3} \mathrm{M}^{-1} \sec ^{-1}$ (RMS $=3 \cdot 72$ per cent).

rate constant of $0.6 \times 10^{-3} \mathrm{M}^{-1} \sec ^{-1}$ is nearly identical to that for a singlecopy tracer DNA reacting with whole nuclear DNA. The about twofold acceleration depends on the greater length both of tracer and of driver (Chamberlin et al., 1978). By forcing a second component to the computer fit only a minimal decrease $(<5$ per cent) in RMS value is achieved. This suggests that almost all genes are represented only once in the haploid genome.

About $82 \%$ of the cDNA reacted with excess RNA (fig. 1). This compares with the 40 per cent plateau reached in DNA excess hybridization (figs. 3 and 4). The difference is not caused by S1 nuclease digestion of cDNA single-stranded tails of hybrids; this can be inferred from the fact that the length of the driver DNA exceeds that of the tracer more than twofold. This can also be deduced from experiments in which hybrids were assayed by HAP chromatography (fig. 3). These experiments displayed an almost identical rate constant and extent of hybridization. Thus it seems clear that the reduced extent of hybridization of the cDNA tracer depends on the unavailability of sufficient complementary DNA sequences. This would affect most seriously abundant class mRNAs. As indicated in table 1 increasing DNA excess indeed increased the extent of hybridization.

It can be concluded therefore that the complex class of mRNA, i.e., the bulk of genes expressed in functional polysomes of barley leaves is not reiterated in the nuclear genome. These are single-copy or at most few-copy $(<5)$ genes since a two or threefold reiteration would remain undetected due to inherent uncertainties in the evaluation of hybridization kinetics.

In order to determine the reiteration frequency of genes coding for abundant class messenger RNA, purified prevalent ${ }^{32} \mathrm{P}-\mathrm{cDNA}$ was hybridized to a large excess of nuclear DNA. The results of this experiment are 
TABLe 1.

Extent of hybridization in dependence on DNA excess

DNA excess Extent of tracer hybridization

$$
\begin{array}{ll}
1 \times 10^{3} & 0.02 \pm 0.003 \\
1 \times 10^{4} & 0.13 \pm 0.02 \\
1 \times 10^{5} & 0.36 \pm 0.04
\end{array}
$$

${ }^{3} \mathrm{H}$-labeled cDNA complementary to total poly(A)mRNA was challenged with varying DNA excess and the amount of tracer in hybrids determined at $C_{0} t 10^{5} \mathrm{M} \mathrm{sec} / \mathrm{l}$. Experiments were replicated three times in the lower DNA excess hybridization experiments and six times with the largest DNA excess employed.

shown in fig. 4. Apparently the kinetics are those of a single kinetic component. The extent of hybridization is about 45 per cent and equals that of the reactability of the tracer when challenged with excess poly(A)mRNA. It seems therefore that the excess of DNA was sufficient to drive the reactable structures into hybrids. This was expected, as ${ }^{32} \mathrm{P}$-dCTP was taken to synthesize the cDNA tracers and specific activities achieved were 100 times that of the total ${ }^{3} \mathrm{H}$-cDNA preparation. The rate constant of hybridization was $1.2 \times 10^{-3}$. This was four times the rate constant of the pure single-copy DNA. However, correcting for length differences between both reactions, this is reduced to a value of $2-3$. Comparison with the rate constant of complex class hybridization gives a twofold, and correcting for tracer DNA length differences a 2-4fold acceleration. These values are

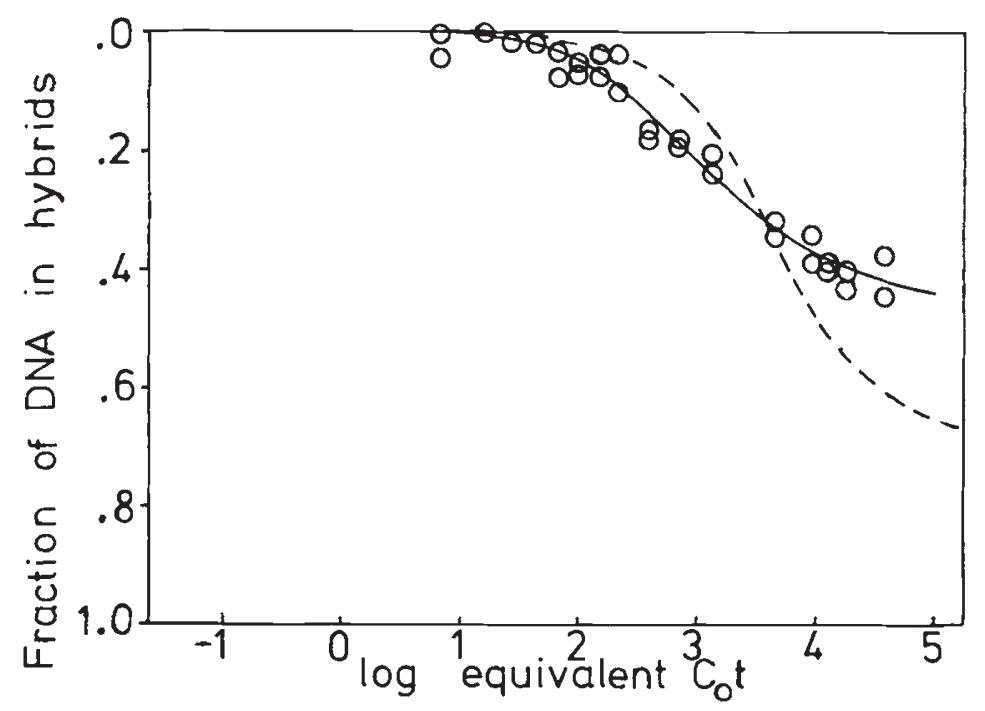

FIG. 4.-Hybridization of prevalent ${ }^{32} \mathrm{P}-\mathrm{cDNA}$ with total nuclear DNA.

Purified prevalent ${ }^{32} \mathrm{P}$-cDNA was hybridized with a $10^{7}$ fold excess of total root nuclear DNA. Samples were analysed by S1 nuclease. The rate constant was $1.2 \times 10^{-3} \mathrm{M}^{-1} \mathrm{sec}^{-1}$ (RMS = 3.4 per cent). The dash-lined curve represents the hybridization of labeled purified unique DNA with a large excess of total nuclear DNA. 
indicative of a reiterated state of genes coding for abundant mRNAs in greened leaves. The reiteration frequency may amount to $2-4$. Due to inherent difficulties in exactly comparing hybridization rate constants it can not be excluded that even the abundant messengers are encoded by genes existing only in one copy per haploid nuclear genome. However, apparently all genes active in greening barley leaves whether expressed abundantly or not seem to belong to that class of DNA which exists only one or a few times in the haploid genome.

\section{Discussion}

In higher plants only one to ten per cent of the unique DNA in the genome codes for structural genes (Goldberg et al., 1978; Kiper et al., $1979 a, b)$. A much larger portion of unique DNA is transcribed into large primary transcripts (Goldberg et al., 1978; Kiper et al., 1979b), presumably containing mRNA fragments which are spliced during processing to give the mature transcripts (Tilghman et al., 1978). Though their main genetic potential obviously is not different, higher plants differ in their haploid genome size by a factor of $1: 1000$ (Rees and Jones, 1972). These large genomic differences are accompanied by a progressive increase in the proportion of repetitive DNA with increasing genome size (Thompson, 1978). It hence was of interest to see whether in a plant with a large nuclear haploid genome like barley this additional DNA is used in a coding capacity.

It has been proven that the functional state of the chloroplast proteins characteristic of plant leaf cells depends on a correct cooperation of nuclear and chloroplast genes. For example, the large subunit of $\mathrm{Ru}-\mathrm{P}_{2}$ is encoded by the chloroplast genome (Coen et al., 1977) while the small subunit apparently is encoded by the nuclear genome (Kawashima and Wildman, 1972). The gene for the large subunit of $\mathrm{Ru}-\mathrm{P}_{2}$ carboxylase may be reiterated several thousandfold per cell as may other structural chloroplast genes (Lamppa and Bendich, 1979). It was hence of interest to see whether genes for abundant leaf mRNA which comprise sequences for the most abundant leaf proteins as LHP and $\mathrm{Ru}-\mathrm{P}_{2}$ carboxylase are reiterated in the nuclear genome.

To test for this, total and abundant poly $(\mathrm{A}) \mathrm{mRNA}$ was prepared from barley leaves; some investigators have reported a poly(A)mRNA of plastome origin (Haff and Bogorad, 1976; Milner and Hershberger, 1979). However, chloroplast polysomal mRNA seems not to be polyadenylated (Wheeler and Hartley, 1975). This explicitly was proven for the plastome coded large subunit of $\mathrm{Ru}-\mathrm{P}_{2}$ carboxylase, one of the major chloroplast proteins (Sagher et al., 1976). So, any interference of chloroplast mRNA hybridizing to DNA can be excluded though the nuclear DNA preparation will not completely be free of chloroplast DNA, even if taking roots as starting material for the isolation of DNA (Lamppa and Bendich, 1979).

Functional polysomes contain both $\operatorname{poly}(\mathrm{A})^{+}$and $\operatorname{poly}(\mathrm{A})^{-} \mathrm{mRNA}^{-}$ though some investigators demonstrated in poly $(\mathrm{A})^{-} \mathrm{mRNA}$ additional information to that contained in poly $(\mathrm{A})^{+}$mRNA (Van Ness et al., 1979; Milcarek, 1979) detailed studies for individual mRNAs proved that these may exist both as poly $(\mathrm{A})^{+}$and poly $(\mathrm{A})^{-}$mRNA (Gedamu et al., 1977; Hunter and Garrels, 1977). We earlier reported that barley ${ }^{3} \mathrm{H}$-unique DNA challenged with total polysomal RNA will not be hybridized to a 
higher degree than will purified poly(A) ${ }^{+}$mRNA itself (Kiper et al., 1979a). We therefore are confident to postulate that our main findings will extend to all functional mRNA in barley.

Total barley leaf poly(A)mRNA consists of about 20-30,000 different species (fig. 1 and Heinze et al., in preparation). Of this about one third makes up almost the whole complexity while another third consists of only 15 different species each on an average being 3000 times as frequent in the leaf cell as does the bulk of the complexity. In DNA excess hybridization of total poly(A)mRNA the most complex class mRNA easily will be hybridized while for the most abundant RNA species it is difficult to obtain true DNA excess conditions. As indicated in table 1 the extent of hybridization is governed strongly by the DNA excess employed. For experiments shown in fig. 3 this was $10^{5}$. So, an 800 times excess of DNA sequences over complementary complex class mRNAs was attained assuming the complex class mRNA not being reiterated in the genome (about 30 per cent of all poly(A)mRNA consisted of about 30,000 species, each of them comprising 0.00001 of the whole population; the DNA excess was 100,000 of which 25 per cent were unique DNA; 1 per cent of this hybridized with poly(A)mRNA, evidently the complex class mRNA; so each DNA sequence comprises $0.8 \times 10^{-7}$ of the whole DNA population or an effective 800 times DNA excess under the conditions used). Correspondingly derived for the abundant class, the RNA species on an average were 2.5 times in excess of complementary genomic DNA sequences. Apparently the conditions were such that in the experiments described in fig. 3 the complex class cDNAs were driven into hybrids whereas abundant cDNAs only occasionally were hybridized. Due to the higher specific activity of the cDNA employed, experiments described in fig. 4 were able to drive even abundant cDNAs into hybrids.

As displayed in fig. 2 it was possible to purify abundant cDNAs of specific activity $2 \times 10^{8} \mathrm{cpm} / \mu \mathrm{g}$ which hybridized with completely different kinetics from that for complex mRNA class and characteristic for the most abundant class.

It would seem that, the cDNAs reacting in fig. 1 and 2 are two distinct sets of expressed genes of different abundancy. The reiteration frequency of these two subsets of active genes was looked for as can be seen in fig. 3 and 4 . Apparently both subsets react with kinetics similar to that of purified single-copy DNA. A 2-4 fold reiteration was found for the abundant mRNA class, whereas the complex class of mRNA reacted with kinetics identical to that of unique DNA. Though apparently the kinetics of hybridization are consistent with a unique transition, a small fraction of less than 5 per cent of the reacting material would have gone undetected. The conclusion drawn thus must be restricted though there is no proof for the presence of a fraction of repetitive DNA in either the abundant or the complex class of genes. This is consistent with other findings that in higher plants total polysomal poly $(\mathrm{A})^{+}$mRNA hybridises exclusively to single-copy DNA (Goldberg et al., 1978; Kiper et al., 1979b) and with the results of Cashmore who recently reported that the nuclear gene for $\mathrm{Ru}-\mathrm{P}_{2}$ carboxylase is a single- or few-copy one (Cashmore, 1979).

Acknowledgment.-This research was supported by a grant of the Stiftung Volkswagenwerk. 


\section{REFERENCES}

APEL, K., AND KLOPPSTECH, K. 1978. The plastid membranes of barley (Hordeum vulgare). Eur. J. Biochem., 85, 581-588.

BARTELS, D., AND KIPER, M. 1979. DNA sequence representation in RNA of the higher plant Petroselinum crispum. Pl. Syst. Evol. Suppl., 2, 141-149.

BISHOP, J. O. 1972. Molecular hybridisation of ribonucleic acid with a large excess of deoxyribonucleic acid. Biochem. J., 126, 171-185.

BISHOP, J. O., MORTON, J. G., ROSBASH, M., AND RICHARDSON, M. 1974. Three abundance classes in Hela cell messenger RNA. Nature, 250, 199-204.

BRITTEN, R. J., GRAHAM, D. E., AND NEUFELD, B. R. 1974. Analysis of repeating DNA sequences by reassociation. Methods in Enzymology, Vol XXIX, eds. Grossman, L. and Moldave, K., Academic Press, New York.

CASHMORE, A. R. 1976. Protein synthesis in plant leaf tissue. The sites of synthesis of the major proteins, J. Biol. Chem., 251, 2848-2853.

CASHMORE, A. R. 1979. Reiteration frequency of the gene coding for the small subunit of ribulose-1,5-bisphosphate carboxylase. Cell, 17, 383-388.

CHAMBERLIN, M. E., GALAU, G. A., BRITTEN, R. J., AND DAVIDSON, E. 1978. Studies on nucleic acid reassoziation kinetics: $V$. Effects of disparity in tracer and driver fragment lengths. Nucl. Acids Res., 5, 2073-2094.

COEN, D., BEDBROOK, J. R., BOGORAD, L., AND RICH, A. 1977. Maize chloroplast DNA fragments encoding the large subunit of ribulose bisphosphate carboxylase. Proc. Nat. Acad. Sci. (U.S.A.), 74, 5487-5491.

DAVIDSON, E. H., AND BRITTEN, R. J. 1973. Organisation, transcription and regulation in the animal genome. Quarterly Rev. Biol., 48, 555-613.

FLAVELL, R. B., BENNETT, M. D., SMITH, J. B., AND SMITH, D. B. 1974. Genome size and the proportion of repeated nucleotide sequence DNA in plants. Biochem. Genetics, 12, 257-269.

FRIEDMAN, E. Y., AND ROSBASH, M. 1977. The synthesis of high yields of full-length reverse transcripts of globin mRNA. Nucleic Acids Res., 4, 3455-3471.

GALAU, G. A., KLEIN, W. H., BRITTEN, R. J., AND DAVIDSON, E. H. 1976. Structural gene sets active in embryos and adult tissues of the sea urchin. Cell, 7, 487-505.

GEDAMU, L., IATROU, K., AND DIXON, G. H. 1977. Isolation and characterisation of trout testis protamine mRNAs lacking poly(A). Cell, 10, 443-451.

GOLDBERG, R. B., HOSCHEK, G., KAMALAY, J. C., AND TIMBERLAKE, W. E. 1978. Sequence complexity of nuclear and polysomal RNA in leaves of the tobacco plant. Cell, 14, 123-131.

GRAHAM, D. E. 1978. The isolation of high molecular weight DNA from whole organisms or large tissue masses. Analytical Biochem., 85, 609-613.

HAFF, L. A., AND BOGORAD, L. 1976. Poly(adenylic acid)-containing RNA from plastids of maize. Biochemistry, $15,4110-4115$.

HARRIS, S. E., MEANS, A. R., MITCHELL, W. M., AND O'MALLEY, B. W. 1973. Synthesis of $\left({ }^{3} \mathrm{H}\right)$ DNA complementary to ovalbumin messenger RNA; evidence for limited copies of the ovalbumin gene in chick oviduct. Proc. Nat. Acad. Sci. U.S.A. 70, 3776-3780.

HARRISON, P. R., HELL, A., BIRNIS, G. D., AND PAUL, J. 1972. Evidence for single copies of globin genes in the mouse genome. Nature, 239, 219-221.

HUNTER, T., AND GARRELS, J. I. 1977. Characterisation of the mRNAs for $\alpha$-, $\beta$ - and $\gamma$-actin. Cell, 12, 767-781.

KAWASHIMA, N., AND WILDMAN, S. G. 1972. Mode of inheritance of primary structure in relation to whether chloroplast or nuclear DNA contains the code for a chloroplast protein. Biochim. Biophys. Acta. 262, 42-49.

KIPER, M. 1978. A quick hydroxyapatite chromatography technique especially adapted for work with DNA networks. Analyt. Biochem., 91, 70-74.

KIPER, M., BARTELS, D., AND KÖCHEL, H. 1979 $a$. Gene number estimates in plant tissues and cells. Pl. Syst. Evol. Suppl., 2, 129-140.

KIPER, M., BARTELS, D., HERZFELD, F., AND RICHTER, G. 1979 $b$. The expression of a plant genome in hnRNA and mRNA. Nucleic Acids Res., 6, 1961-1978.

KIPER, M., AND HERZFELD, F. 1978. DNA sequence organisation in the genome of Petroselinum sativum (Umbelliferae). Chromosoma, (Berl.) 65, 335-351.

KLOPPSTECH, K., AND SCHWEIGER, H. G. 1976. In vitro translation of poly(A)RNA from Acetabularia. Cytobiologie, 13, 394-400. 
LAMPPA, G. K., AND BENDICH, A. J. 1979. Changes in chloroplast DNA levels during development of pea (Pisum sativum). Plant Physiol., 64, 126-130.

MILCAREK, C. 1979. Hela cell cytoplasmic mRNA contains three classes of sequences: predominantly poly(A)-free, predominantly poly(A)-containing and bimorphic. Eur. J. Biochem., 102, 467-476.

MILNER. J. J., AND HERSHBERGER, C. L. 1979. Euglena gracilis chloroplast DNA codes for polyadenylated RNA. Plant Physiol., 64, 818-821.

PASCOE, M. J., AND INGLE, J. 1978. Distinction between nuclear satellite DNAs and chloroplast DNA in higher plants. Plant Physiol., 62, 975-977.

PFISTERER, J., AND KLOPPSTECH, K. 1977. Free and membrane bound polysomes from plant cell cultures. In: Colloques Internat. $d u$ CNRS, 261, 279-283 Editions CNRS, Paris.

REES, H., AND JONES, R. N. 1972. The origin of the wide species variation in nuclear DNA content. Internat. Rev. Cytol., 32, 53-92.

SAGHER, D., GROSFELD, H., AND EDELMAN, M. 1976. Large subunit ribulose bisphosphate carboxylase messenger RNA from Euglena chloroplasts. Proc. Nat. Acad. Sci. U.S.A., 73, 722-726.

THOMPSON, W. F. 1978. Perspectives on the evolution of plant DNA. Carnegie Institution Year Book, 77, 310-316.

TILGHMAN, S., M. CURTIS, P. J., TIEMEIER, D. C., LEDER, P., AND WEISSMAN, C. 1978. The intervening sequence of a mouse $\beta$-globin gene is transcribed within the $15 \mathrm{~S} \beta$-globin mRNA precursor. Proc. Nat. Acad. Sci. U.S.A. 75, 1309-1313.

VAN NESS, J., MAXWELL, J. H., AND HAHN, W. E. 1979. Complex population of nonpolyadenylated messenger RNA in mouse brain. Cell, 18, 1341-1349.

WEINBERG, E. S., BIRNSTIEL, M. L., PURDOM, J., AND WILLIAMSON, R. 1972. Genes coding for polysomal 9 S RNA of sea urchins: conservation and divergence. Nature, 240, 225228.

WHEELER, A: M., AND HARTLEY, M. R. 1975. Major mRNA species from spinach chloroplasts do not contain poly(A). Nature, 257, 66-67. 